Article

\title{
In Vitro Regeneration and ISSR-Based Genetic Fidelity Analysis of Orthosiphon stamineus Benth
}

\author{
Hanisah Ali ${ }^{1}$, Izzah Farhanah Musa ${ }^{1}$, Nurul Atikhah Abu Bakar ${ }^{1}$, Saiful Anuar Karsani ${ }^{1}$ and \\ Jamilah Syafawati Yaacob 1,2,*(D) \\ 1 Institute of Biological Sciences, Faculty of Science, University of Malaya, Kuala Lumpur 50603, Malaysia; \\ hanisahisb@gmail.com (H.A.); if_moses@yahoo.com (I.F.M.); nurul_atikhah@siswa.um.edu.my (N.A.A.B.); \\ saiful72@um.edu.my (S.A.K.) \\ 2 Centre for Research in Biotechnology for Agriculture (CEBAR), University of Malaya, Kuala \\ Lumpur 50603, Malaysia \\ * Correspondence: jamilahsyafawati@um.edu.my; Tel.: +603-79674090
}

Received: 25 September 2019; Accepted: 8 November 2019; Published: 20 November 2019

check for updates

\begin{abstract}
Orthosiphon stamineus has been widely used as traditional remedy for various illnesses and diseases, such as cardiovascular diseases and epileptic seizures. In this study, direct regeneration through nodal segment of this species was attempted using Kinetin (6-Furfurylaminopurine) and IAA (indole-3-acetic acid). Optimum regeneration media was identified as MS media supplemented with $2.0 \mathrm{mg} \mathrm{L}^{-1} \mathrm{Kin}$ plus $0.5 \mathrm{mg} \mathrm{L}^{-1}$ IAA. This yielded the highest number of shoots $(5.57 \pm 0.42)$ and leaves $(20.53 \pm 1.91)$ per explant. Acclimatization of the resulting in vitro regenerants was successful in all potting mixtures tested. However, potting mixture PF (1:1:1 ratio of black soil/red soil/compost) was identified as the best medium for acclimatization of this species, as it yielded $100 \%$ survival percentage after 90 days of acclimatization. Ten in vitro regenerants of $O$. stamineus were randomly collected after the third subculture and subjected to genetic variation analysis using inter-simple sequence repeat (ISSR) markers. Out of 20 ISSR markers tested, 10 working primers were observed to produce satisfactory amplification of bands, with an average of 7.11 bands per primer. A total of 610 bands were produced by the 10 primers. The percentage of polymorphism was observed to be very low, yielding only $7.32 \%$ polymorphism among all samples. Jaccard dissimilarity analysis was also conducted and very low genetic distance (about 0.1 ) was found among the in vitro regenerants and between the regenerants with the mother plant, thus ascertaining the clonal nature of the plantlets produced in this study.
\end{abstract}

Keywords: Orthosiphon stamineus; micropropagation; genetic fidelity; clonal; genetic distance; ISSR

\section{Introduction}

Orthosiphon stamineus, commonly known as Misai Kucing, has been widely used as a traditional remedy for various illnesses. This species can be found throughout Southeast Asia and tropical Australia. The leaves have also been introduced to Europe and Japan as a health tea, known as Java tea. The flowers resemble cat whiskers, with long wispy-shaped stamen [1]. This species has been reported to improve general health effectively, as well as to be a known remedy for kidney diseases, bladder inflammation, gout, and diabetes [2]. Other than that, O. stamineus is also used to treat rheumatism, tonsillitis, and menstrual disorder [3-5]. The leaves were found to possess diuretic $[6,7]$ and anti-hypertensive activities $[3,8]$. Several bioactive compounds that are present in this plant, such as sterols, terpenoids, and polyphenols, have contributed to its therapeutic effects. Bioactive polyphenols in $\mathrm{O}$. stamineus have the ability to protect the human body from oxidative stress associated with many diseases such as cancer [8,9], cardiovascular diseases, and aging [10]. A recent study has 
shown that the methanolic extract of $O$. stamineus leaves also possess hepatoprotective properties [11]. Java tea extracts are also used as food or feed additives to protect the intestine from oxidative stress [12], as a novel symptomatic treatment for epileptic seizures [13], and has anti-obesity effects [14]. This species has been studied extensively for its medicinal benefits. The vast medicinal properties of this species have rendered it to be extremely important and always in high demand, thus requiring for its mass propagation.

Traditionally, breeding of this species is accomplished via vegetative propagation through mature stem, but the supply was inadequate for market demand $[15,16]$. To fit the demand, plant growth regulators (PGRs) are used to produce a large number of crops and seed germination [17]. For example, NAA and BAP have been widely used to induce production of shoots from various explant types of O. stamineus [18-21]. Moreover, both PGRs have also been reported to yield production of callus for establishment of cell suspension culture of this species [22,23]. In comparison, the use of other PGRs in tissue culture of $O$. stamineus has not been widely highlighted. Therefore, the present study aims to evaluate the efficiency of indole-3-acetic acid (IAA) and kinetin for efficient micropropagation of this species.

In vitro micropropagation is an efficient technique to generate a large supply of crops in shorter time. During in vitro culture, variability can also occur spontaneously and can be a result of temporary changes or permanent genetic changes in cells or tissues. Temporary changes result from epigenetic or physiological effects and are non-heritable and reversible. In contrast, permanent changes are heritable and often represent expression of pre-existing variation in the source plant [24]. There are a lot of factors that contribute to the occurrence of somaclonal variation phenomenon. These include the system by which the regeneration is induced, type of tissue, explant source, media components, and the duration of the culture cycle [25]. Somaclonal variation has been reported to cause regenerants to exhibit variations in terms of morphological, cytological, cytochemical, biochemical, and also at the molecular level [26]. Genetic variability is usually influenced by several factors, such as natural selection, mutation, migration, and population size, in different ways. Variation in chromosome numbers and structures, and chromosome irregularities such as breaks, acentric and centric fragments, ring chromosomes, deletions, and inversions, may result in the loss of genes or their function, the activation of genes which were previously silent, and the expression of recessive genes, once they become haploid $[27,28]$. There is a high risk that the regenerated plant will lose its fidelity to the parent plant due to the multicellular origin of adventitious buds used as the explant source.

In this paper, the efficiency of indole-3-acetic acid (IAA) and kinetin in aiding micropropagation of $O$. stamineus was highlighted, to complement and further add to the knowledge in tissue culture protocols of this species. The genetic fidelity of the regenerants were also assessed and compared to the mother plant using inter-simple sequence repeat (ISSR) markers, to elucidate any occurrence of somaclonal variation. Acclimatization of the plantlets to ex vitro environments was also carried out to ensure the success of the tissue culture experiments conducted.

\section{Materials and Methods}

\subsection{Preparation of Growth Media and Plant Material}

In this study, MS [29] media was prepared using $4.4 \mathrm{~g} \mathrm{~L}^{-1}$ Murashige and Skoog (MS) powder added with $30 \mathrm{~g} \mathrm{~L}^{-1}$ sucrose as carbon source and $2 \mathrm{~g} \mathrm{~L}^{-1}$ Gelrite Gellan Gum (Duchefa Biochemie B.V, 2003 Netherlands) as the gelling agent. Then, $0.5-2.0 \mathrm{mg} \mathrm{L}^{-1}$ indole-3-acetic acid (IAA) and Kinetin (Kin) were supplemented to the media, either singly or at different combinations. The $\mathrm{pH}$ of the media was adjusted to $5.7-5.8$ using $0.1 \mathrm{M} \mathrm{NaOH}$ or $0.1 \mathrm{M} \mathrm{HCl}$ before being autoclaved at $121^{\circ} \mathrm{C}$ for $20 \mathrm{~min}$.

Explants were excised from the nodal segment of a field-grown O. stamineus mother plant. Surface sterilization was conducted by washing all samples taken from the field-grown plant under tap water for $1 \mathrm{~h}$, and subsequently treated with commercial bleach, i.e., Clorox (50\% and 30\%), (v/v) for $1 \mathrm{~min}$, then rinsed with sterile distilled water after each treatment to remove excess Clorox. Two drops of 
Tween 20 were added with $50 \%$ of Clorox. Then samples were treated with $70 \%$ ethanol (v/v) for $1 \mathrm{~min}$, followed by rinsing three times with sterile distilled water. Samples were blot dried on sterile tissue paper before being cultured.

\subsection{Induction of Direct Regeneration}

The nodal region was excised (approximately $1.0 \mathrm{~cm}$ in height) from the mother plant and cultured in sterile tubes containing MS media supplemented with various concentrations of IAA and Kin. All cultures were maintained in a culture room at $25 \pm 1{ }^{\circ} \mathrm{C}$ for $16 \mathrm{~h}$ light and $8 \mathrm{~h}$ dark under 1000 lux (14-15 $\mu \mathrm{mol} \mathrm{m}^{-2} \mathrm{~s}^{-1}$ ) of light intensity. The morphology of the resulting regenerants (number of shoots, leaves, and roots), as well as production of callus, were observed for 4 weeks. The multiplication index was also analyzed by calculating the number of newly formed shoots per initial shoot tip recorded [30]. Experiments were conducted in triplicates of $n=10$ and followed a randomized complete block design (RCBD). Data analysis was conducted using analysis of variance (ANOVA) and Duncan's multiple range test (DMRT) at 5\% significance level.

\subsection{Acclimatization}

Fifteen rooted plantlets with fully expanded leaves were acclimatized on 6 different types of sterilized commercial potting mixture, which are black soil, red soil, black soil/red soil (1:1), black soil/compost (1:1), red soil/compost (1:1) and black soil/red soil/compost (1:1:1). The potting mixtures were purchased from a nearby nursery. Acclimatization was conducted at $25 \pm 1{ }^{\circ} \mathrm{C}$ under $16-\mathrm{h}$ photoperiod with 1000 lux (14-15 $\left.\mu \mathrm{mol} \mathrm{m}{ }^{-2} \mathrm{~s}^{-1}\right)$ of light intensity. The plantlets were transferred to a jam jar containing the different potting mixtures, sealed with plastic wrap, and left to acclimatize for 1 month. The plastic wrap was pricked in stages (at timely interval) until the jam jar was fully exposed. Plantlets were subsequently transferred into plastic pots after 3 months. Survival data were collected after 30, 60, and 90 days, and data were analyzed using analysis of variance (ANOVA) and Duncan's multiple range test (DMRT) at $5 \%$ significance level.

\subsection{DNA Isolation and ISSR Analysis}

Ten random in vitro plantlets were harvested and used for molecular analysis. Genomic DNA was isolated using $50 \mathrm{mg}$ fresh leaves of $O$. stamineus (after the third subculture) according to i-genomic Plant DNA Extraction Mini Kit (iNtRON Biotechnology Inc., Gyeonggi-do, South Korea). The concentration of DNA extracted was determined using a nanophotometer (IMPLEN, Munich, Germany).

Twenty ISSR primers [31] were tested in this study (Table S1 in Supplementary Material). PCR amplification was performed in a total of $20 \mu \mathrm{l}$ reaction volume containing $1 \mu \mathrm{l}$ of template DNA at concentration of $50 \mathrm{ng} \mu \mathrm{l}^{-1}, 0.5 \mu \mathrm{l}$ of primer at concentration of $0.50 \mu \mathrm{M}, 0.2 \mu \mathrm{l}$ at concentration of $20 \mathrm{mg} \mu \mathrm{l}^{-1}$ of BSA (Fermentas, Vilnius, Lithuania), $2.0 \mu \mathrm{l}$ of buffer (EURx, Gdańsk, Poland) at 10X concentration, $1.0 \mu \mathrm{l}$ of dNTP's at concentration of $4.0 \mathrm{mM}$ (Invitrogen, Carlsbad, California, USA), $1.0 \mu \mathrm{l}$ of $\mathrm{MgCl} 2$ (EURx, Gdańsk, Poland) at a concentration of $50 \mathrm{mM}, 2.5$ unit of $0.5 \mu \mathrm{l}$ Taq polymerase (EURx, Gdańsk, Poland). Then, 10x Pol Buffer C was used (enriched with two gel tracking dyes and a gel loading reagent). Amplification was performed using Thermocycler (Eppendorf, Hamburg, Germany) with the following conditions: Initial denaturation at $94{ }^{\circ} \mathrm{C}$ for $5 \mathrm{~min}$, followed by 35 cycles of denaturation step at $94^{\circ} \mathrm{C}$ for $1 \mathrm{~min}, 1 \mathrm{~min}$ at specific annealing temperature, extension step at $72^{\circ} \mathrm{C}$ for $2 \mathrm{~min}$, and 1 cycle of final extension step at $72{ }^{\circ} \mathrm{C}$ for $10 \mathrm{~min}$. Next, $1.5 \%$ agarose gel (1X TAE) was used to resolve the amplified product, then visualized under UV light. TrackIt ${ }^{\mathrm{TM}} 1 \mathrm{~Kb}$ Plus DNA ladder (Invitrogen, Carlsbad, California, USA) was used for sizing of the DNA bands.

All data were compiled as a binary character matrix. The bands were scored as presence (1) and absence (0) for each sample through manual scoring, and triple-checked to minimize errors. Faint and ambiguous bands were excluded from the statistical analysis. Jaccard's coefficients were used to calculate the genetic dissimilarity between the samples using Darwin 5.0 software [32]. 


\section{Results}

\subsection{Direct Regeneration In Vitro}

Emergence of new shoots could be observed after 1 week of culture. Most samples showed direct regeneration of shoots and roots. Morphological data such as number of shoots, leaves, and roots, as well as number of explants producing callus, were collected for 4 weeks (Tables 1 and 2). No roots and callus formation were observed in control media; MS basal (Tables 1 and 2). Generally, media supplemented with combinations of Kin and IAA hormones showed better production of shoots and leaves than media supplemented with either Kin or IAA only.

Table 1. Effects of single hormone on number of shoots, multiplication index, leaves and roots per explant, and percentage (\%) of explant producing callus.

\begin{tabular}{cccccc}
\hline $\begin{array}{c}\text { MS + } \\
\text { Hormone } \\
\left(\mathbf{m g ~ L}^{-1}\right)\end{array}$ & $\begin{array}{c}\text { Number of } \\
\text { Shoots per } \\
\text { Explant }\end{array}$ & $\begin{array}{c}\text { Multiplication } \\
\text { Index }\end{array}$ & $\begin{array}{c}\text { Number of } \\
\text { Leaves per } \\
\text { Explant }\end{array}$ & $\begin{array}{c}\text { Number of } \\
\text { Roots per } \\
\text { Explant }\end{array}$ & $\begin{array}{c}\text { Percentage (\%) of } \\
\text { Explant Producing } \\
\text { Callus }\end{array}$ \\
\hline Control & $2.67 \pm 0.09 \mathrm{a}$ & $1.67 \pm 0.09 \mathrm{a}$ & $4.21 \pm 0.32 \mathrm{a}$ & $\mathrm{NR}$ & $\mathrm{NR}$ \\
$0.5 \mathrm{Kin}$ & $2.90 \pm 0.11 \mathrm{a}$ & $1.89 \pm 0.11 \mathrm{~b}$ & $8.93 \pm 0.47 \mathrm{~b}$ & $0.31 \pm 0.10 \mathrm{a}$ & $93.33 \pm 0.05 \mathrm{~b}$ \\
$1.0 \mathrm{Kin}$ & $3.77 \pm 0.16 \mathrm{~b}$ & $2.77 \pm 0.16 \mathrm{~b}$ & $11.70 \pm 0.70 \mathrm{c}$ & $1.03 \pm 0.30 \mathrm{a}$ & $40.00 \pm 0.09 \mathrm{a}$ \\
1.5 Kin & $4.00 \pm 0.32 \mathrm{~b}$ & $3.00 \pm 0.32 \mathrm{~b}$ & $15.10 \pm 0.15 \mathrm{~d}$ & $0.34 \pm 0.12 \mathrm{a}$ & $90.00 \pm 0.06 \mathrm{~b}$ \\
2.0 Kin & $3.90 \pm 0.23 \mathrm{~b}$ & $2.90 \pm 0.23 \mathrm{~b}$ & $13.00 \pm 1.09 \mathrm{c}$ & $0.23 \pm 0.10 \mathrm{a}$ & $96.67 \pm 0.03 \mathrm{~b}$ \\
0.5 IAA & $3.63 \pm 0.09 \mathrm{~b}$ & $2.63 \pm 0.09 \mathrm{~b}$ & $9.23 \pm 0.49 \mathrm{~b}$ & $2.93 \pm 0.64 \mathrm{~b}$ & $50.00 \pm 0.09 \mathrm{a}$ \\
1.0 IAA & $2.62 \pm 0.13 \mathrm{a}$ & $1.62 \pm 0.13 \mathrm{a}$ & $8.69 \pm 0.55 \mathrm{~b}$ & $4.00 \pm 0.74 \mathrm{bc}$ & $80.00 \pm 0.07 \mathrm{~b}$ \\
1.5 IAA & $2.55 \pm 0.11 \mathrm{a}$ & $1.55 \pm 0.11 \mathrm{a}$ & $9.28 \pm 0.65 \mathrm{~b}$ & $3.31 \pm 0.61 \mathrm{bc}$ & $96.67 \pm 0.03 \mathrm{~b}$ \\
2.0 IAA & $2.63 \pm 0.12 \mathrm{a}$ & $1.63 \pm 0.12 \mathrm{a}$ & $7.77 \pm 0.67 \mathrm{~b}$ & $4.60 \pm 0.65 \mathrm{c}$ & $96.67 \pm 0.03 \mathrm{~b}$ \\
\hline
\end{tabular}

Data represent mean value \pm standard error (SE) with 30 explants in each treatment. Means with different letters within the same column are significantly different at $p<0.05$, according to Duncan's multiple range test (DMRT). Kin, Kinetin; IAA, indole-acetic acid; NR, no response.

Table 2. Effects of combination hormones on number of shoots, multiplication index, leaves and roots per explant, and percentage (\%) of explant producing callus.

\begin{tabular}{|c|c|c|c|c|c|}
\hline $\begin{array}{c}\text { MS + Hormone } \\
\left(\mathrm{mg} \mathrm{L}^{-1}\right)\end{array}$ & $\begin{array}{c}\text { Number of Shoots } \\
\text { Per Explant }\end{array}$ & $\begin{array}{l}\text { Multiplication } \\
\text { Index }\end{array}$ & $\begin{array}{c}\text { Number of Leaves } \\
\text { per Explant }\end{array}$ & $\begin{array}{l}\text { Number of } \\
\text { Roots per } \\
\text { Explant }\end{array}$ & $\begin{array}{c}\text { Percentage }(\%) \text { of } \\
\text { Explant Producing } \\
\text { Callus }\end{array}$ \\
\hline Control & $2.67 \pm 0.09 \mathrm{a}$ & $1.67 \pm 0.09 \mathrm{a}$ & $4.21 \pm 0.32 \mathrm{a}$ & NR & NR \\
\hline $0.5 \mathrm{Kin}+0.5 \mathrm{IAA}$ & $2.93 \pm 0.14 \mathrm{ab}$ & $1.93 \pm 0.14 \mathrm{ab}$ & $10.20 \pm 0.65 b$ & $0.73 \pm 0.21 \mathrm{abcd}$ & $100.00 \pm 0.00 \mathrm{~b}$ \\
\hline $0.5 \mathrm{Kin}+1.0 \mathrm{IAA}$ & $3.23 \pm 0.11 \mathrm{abcd}$ & $2.23 \pm 0.11 \mathrm{abcd}$ & $12.70 \pm 0.51$ bcde & $1.60 \pm 0.28 \mathrm{de}$ & $93.33 \pm 0.05 b$ \\
\hline $0.5 \mathrm{Kin}+1.5 \mathrm{IAA}$ & $3.13 \pm 0.20 a b c$ & $2.13 \pm 0.19 a b c$ & $11.20 \pm 0.58 b$ & $1.07 \pm 0.42$ bcde & $80.00 \pm 0.07 \mathrm{a}$ \\
\hline $0.5 \mathrm{Kin}+2.0 \mathrm{IAA}$ & $2.87 \pm 0.14 \mathrm{ab}$ & $1.87 \pm 0.14 \mathrm{ab}$ & $12.11 \pm 0.84 \mathrm{bcd}$ & $1.93 \pm 0.59 \mathrm{e}$ & $96.67 \pm 0.03 b$ \\
\hline $1.0 \mathrm{Kin}+0.5 \mathrm{IAA}$ & $3.77 \pm 0.16 \mathrm{ab}$ & $2.77 \pm 0.16$ cdefg & $11.30 \pm 1.01 \mathrm{bc}$ & $1.80 \pm 0.60 \mathrm{cde}$ & $93.33 \pm 0.05 b$ \\
\hline $1.0 \mathrm{Kin}+1.0 \mathrm{IAA}$ & $4.53 \pm 0.25$ cdefg & $3.53 \pm 0.25 \mathrm{~g}$ & $12.03 \pm 0.86 \mathrm{bcd}$ & $1.47 \pm 0.48 \mathrm{de}$ & $96.67 \pm 0.03 b$ \\
\hline $1.0 \mathrm{Kin}+1.5 \mathrm{IAA}$ & $4.10 \pm 0.16 \mathrm{efg}$ & $3.10 \pm 0.16 \mathrm{efg}$ & $10.52 \pm 0.60 b$ & $0.10 \pm 0.07 \mathrm{a}$ & $100.00 \pm 0.00 \mathrm{~b}$ \\
\hline $1.0 \mathrm{Kin}+2.0 \mathrm{IAA}$ & $4.43 \pm 0.17 \mathrm{~g}$ & $3.43 \pm 0.18 \mathrm{~g}$ & $11.60 \pm 0.91 b$ & $0.43 \pm 0.18 \mathrm{abc}$ & $96.67 \pm 0.03 b$ \\
\hline $1.5 \mathrm{Kin}+0.5 \mathrm{IAA}$ & $4.23 \pm 0.28 \mathrm{fg}$ & $3.23 \pm 0.28 \mathrm{fg}$ & $15.80 \pm 0.89 \mathrm{ef}$ & $0.07 \pm 0.05 \mathrm{a}$ & $70.00 \pm 0.09 a$ \\
\hline $1.5 \mathrm{Kin}+1.0 \mathrm{IAA}$ & $3.93 \pm 0.29 \mathrm{defg}$ & $2.93 \pm 0.29 \mathrm{defg}$ & $15.53 \pm 1.29 \mathrm{ef}$ & $0.27 \pm 0.14 \mathrm{abc}$ & $100.00 \pm 0.00 \mathrm{~b}$ \\
\hline $1.5 \mathrm{Kin}+1.5 \mathrm{IAA}$ & $3.40 \pm 0.17$ abcde & $2.40 \pm 0.17$ abcde & $12.11 \pm 0.87 \mathrm{bcd}$ & $0.15 \pm 0.08 a b$ & $100.00 \pm 0.00 \mathrm{~b}$ \\
\hline $1.5 \mathrm{Kin}+2.0 \mathrm{IAA}$ & $4.20 \pm 0.26 \mathrm{fg}$ & $3.20 \pm 0.26 \mathrm{fg}$ & $15.23 \pm 1.12 \mathrm{def}$ & $0.70 \pm 0.23 \mathrm{abcd}$ & $93.33 \pm 0.05 b$ \\
\hline $2.0 \mathrm{Kin}+0.5 \mathrm{IAA}$ & $5.57 \pm 0.42 \mathrm{~h}$ & $4.57 \pm 0.42 \mathrm{~h}$ & $20.53 \pm 1.91 \mathrm{~g}$ & $0.73 \pm 0.27 \mathrm{abcd}$ & $93.33 \pm 0.05 b$ \\
\hline $2.0 \mathrm{Kin}+1.0 \mathrm{IAA}$ & $3.60 \pm 0.24$ bcdef & $2.60 \pm 0.24$ bcdef & $16.83 \pm 1.21 \mathrm{f}$ & $1.69 \pm 0.29 \mathrm{de}$ & $100.00 \pm 0.00 \mathrm{~b}$ \\
\hline $2.0 \mathrm{Kin}+1.5 \mathrm{IAA}$ & $4.20 \pm 0.36 \mathrm{fg}$ & $3.20 \pm 0.36 \mathrm{fg}$ & $14.50 \pm 1.42 \mathrm{cdef}$ & $0.27 \pm 0.15 \mathrm{abc}$ & $96.67 \pm 0.03 b$ \\
\hline $2.0 \mathrm{Kin}+2.0 \mathrm{IAA}$ & $4.40 \pm 0.27 \mathrm{~g}$ & $3.40 \pm 0.27 \mathrm{~g}$ & $15.07 \pm 1.08 \mathrm{def}$ & $0.83 \pm 0.30 \mathrm{abcd}$ & $96.67 \pm 0.03 b$ \\
\hline
\end{tabular}

Data represent mean value \pm standard error (SE) with 30 explants in each treatment. Means with different letters within the same column are significantly different at $p<0.05$, according to Duncan's multiple range test (DMRT). Kin, Kinetin; IAA, indole-acetic acid; NR, no response.

The presence of Kin (singly applied) in the media was found to improve production of new shoots and leaves, but did not affect root formation (Table 1). Contrasting results were observed when only IAA was added to media, where it only aided root formation but yielded no effect on shoot or leaf production (Table 1). Supplementation of high Kin concentration (1.0-2.0 $\mathrm{mg} \mathrm{L}^{-1}$ ) yielded the most number of shoots and leaves among all single PGR treatments (Table 1). 
When both PGRs were used in combination, production of new shoots and leaves were observed to be significantly improved. As shown in Table 2, addition of $2.0 \mathrm{mg} \mathrm{L}^{-1} \mathrm{Kin}$ plus $0.5 \mathrm{mg} \mathrm{L}^{-1} \mathrm{IAA}_{\text {in }}$ the media (identified as the optimum regeneration media) resulted in the highest number of shoots $(5.57 \pm 0.42)$ and leaves $(20.53 \pm 1.91)$ per explant. The optimum regeneration media also yielded the highest multiplication index $(4.57 \pm 0.42)$ among other treatments. However, combined PGRs were observed to reduce production of roots, where more number of roots were produced when only IAA was added in the media (Tables 1 and 2).

\subsection{Production of Callus}

In contrast to the control (cultures on MS basal), all cultures produced on MS media supplemented with PGRs (either singly applied or combined) showed production of callus, indicating that callus induction in this species relied on supplementation of PGRs (Tables 1 and 2). However, the degree of callus production was observed to be non-uniform and not concentration-dependent, except when the media was added with IAA (singly applied). The lowest percentage of explants producing callus was observed in MS media supplemented with $1.0 \mathrm{mg} \mathrm{L}^{-1} \mathrm{Kin}(40 \%)$ and $0.5 \mathrm{mg} \mathrm{L}^{-1}$ IAA (50\%). On the other hand, more than $70 \%$ of the explants produced callus when cultured on MS media added to with both IAA and Kin (Table 2).

\subsection{Acclimatization}

In this study, most of the regenerated plantlets were successfully acclimatized (Table 3). Only plantlets with fully expanded roots and leaves were used as samples in this assessment (Figure 1). After 30 days of acclimatization, only plantlets transplanted into potting mixture PD and PF showed $100 \%$ survival rate. However, the survival rate of the acclimatized plantlets on potting mixture PD declined after 60 days. Data analysis also indicated that potting mixture containing only black soil (PA) was the most unfavorable medium for acclimatization of this species, as it resulted in the highest decrease of survival rate with time (Table 3). On the other hand, the best medium for acclimatization of O. stamineus plantlets was observed to be potting mixture PF (1:1:1 ratio of black soil/red soil/compost), as $100 \%$ of the plantlets survived after 90 days of acclimatization (Table 3).

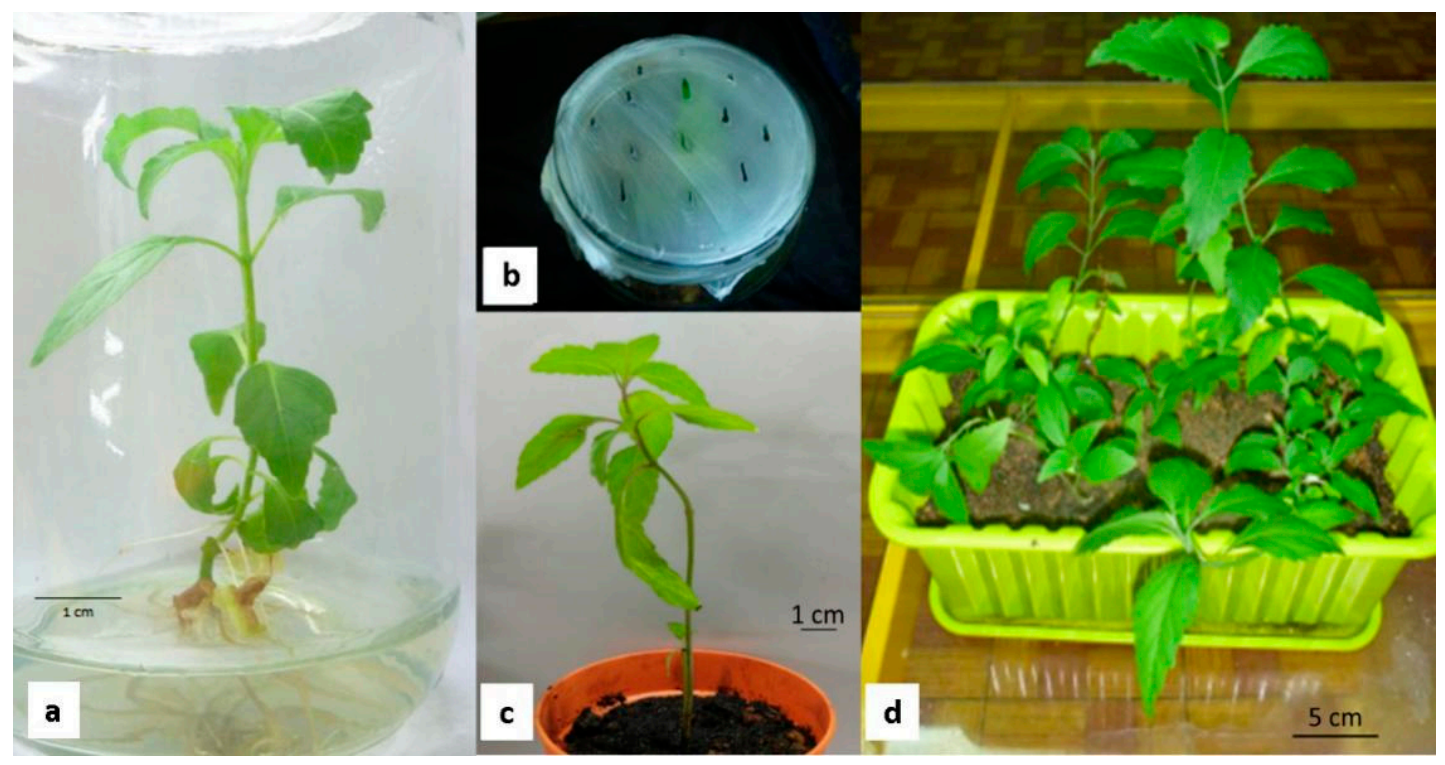

Figure 1. Acclimatization of regenerated plantlets of Orthosiphon stamineus; (a) in vitro grown plantlet, (b) acclimatization after 30 days, (c) acclimatization after 90 days, and (d) several successfully acclimatized plantlets after 6 months. 
Table 3. Acclimatization of regenerated plantlets of Orthosiphon stamineus.

\begin{tabular}{ccccc}
\hline Sample ID & Potting Mixture & $\begin{array}{c}\text { Survival \% after } \\
\text { 30 Days }\end{array}$ & $\begin{array}{c}\text { Survival \% after } \\
\text { 60 Days }\end{array}$ & $\begin{array}{c}\text { Survival \% after } \\
\text { 90 Days }\end{array}$ \\
\hline PA & Black soil & $66.67 \pm 12.60 \mathrm{ab}$ & $40.00 \pm 13.09 \mathrm{a}$ & $26.67 \pm 11.82 \mathrm{a}$ \\
\hline PB & Red soil & $57.14 \pm 12.78 \mathrm{a}$ & $57.14 \pm 12.78 \mathrm{ab}$ & $57.14 \pm 12.78 \mathrm{~b}$ \\
\hline PC & Black soil + red soil & $78.57 \pm 10.60 \mathrm{abc}$ & $64.33 \pm 12.37 \mathrm{abc}$ & $64.33 \pm 12.37 \mathrm{bc}$ \\
\hline PD & Black soil + compost & $100.00 \pm 0.00 \mathrm{c}$ & $92.31 \pm 6.63 \mathrm{~cd}$ & $92.31 \pm 6.63 \mathrm{~cd}$ \\
\hline PE & Red soil + compost & $86.67 \pm 9.09 \mathrm{bc}$ & $86.67 \pm 9.09 \mathrm{bcd}$ & $80.00 \pm 10.69 \mathrm{bcd}$ \\
\hline PF & Black soil + red soil + compost & $100.00 \pm 0.00 \mathrm{c}$ & $100.00 \pm 0.00 \mathrm{~d}$ & $100.00 \pm 0.00 \mathrm{~d}$ \\
\hline
\end{tabular}

Data represent mean value \pm standard error (SE) with 15 explants in each treatment. Means with different letters within the same column are significantly different at $p<0.05$, according to Duncan's multiple range test (DMRT).

\subsection{ISSR Analysis}

Ten out of 20 tested ISSR primers produced satisfactory amplification of bands in this study (data not shown). Bands observed were fairly clear (Figure 2). A total of 610 scorable bands were generated from 10 random $O$. stamineus in vitro plantlets (Table 4). The total number of bands amplified per primer varied from 36 to 100 per primer. The range of amplification was between 300 to $2500 \mathrm{bp}$. Only 4 primers (UBC845, UBC836, UBC841, and UBC856) showed polymorphism with $7.32 \%$ polymorphism in total number of bands.

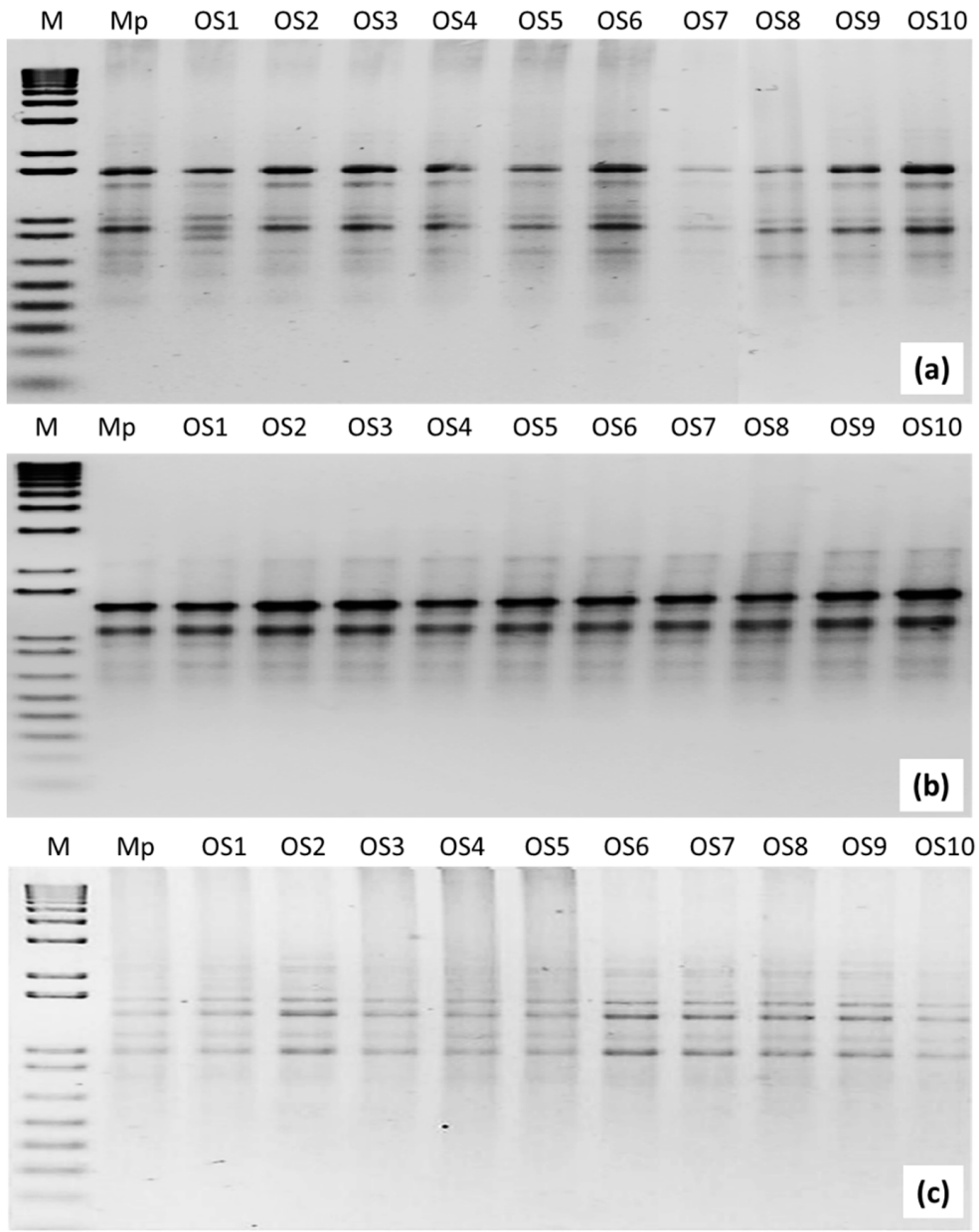

Figure 2. Polymerase chain reaction (PCR) amplification products obtained with inter-simple sequence repeat (ISSR) markers; (a) Primer UBC841, (b) Primer UBC835, and (c) Primer UBC855. Lane M: Molecular marker (100 bp-15 kbp); Lane Mp: Mother plant; Lanes OS1-OS10: In vitro-raised Ortosiphon stamineus plantlets. 
Table 4. Primer used in ISSR polymorphism analysis, number and size of amplified fragments of Orthosiphon stamineus.

\begin{tabular}{|c|c|c|c|c|c|c|}
\hline $\begin{array}{c}\text { Primer } \\
\text { Code(UBC) }\end{array}$ & $\begin{array}{c}\text { Sequence } \\
5^{\prime}-3^{\prime}\end{array}$ & $\begin{array}{c}\text { Annealing } \\
\text { Temperature } \\
\left({ }^{\circ} \mathrm{C}\right)\end{array}$ & $\begin{array}{c}\text { Total } \\
\text { Number of } \\
\text { Bands } \\
\text { Amplified }\end{array}$ & $\begin{array}{l}\text { Number of } \\
\text { Scorable } \\
\text { Bands per } \\
\text { Primer }\end{array}$ & $\begin{array}{c}\text { No. and } \\
\text { Frequency of } \\
\text { Polymorphic } \\
\text { Bands per Primer }\end{array}$ & $\begin{array}{c}\text { Range of } \\
\text { Amplification } \\
\text { (bp) }\end{array}$ \\
\hline UBC807 & $(\mathrm{AG})_{8} \mathrm{~T}$ & 46.5 & 68 & 8 & 0 & $500-2000$ \\
\hline UBC829 & $(\mathrm{TG})_{8} \mathrm{C}$ & 52.5 & 80 & 8 & 0 & $600-1300$ \\
\hline UBC 835 & $(\mathrm{AG})_{8} \mathrm{YC}$ & 50.0 & 59 & 7 & $2(28.57 \%)$ & $550-2500$ \\
\hline UBC836 & $(\mathrm{AG})_{8} \mathrm{YA}$ & 48.0 & 68 & 11 & $1(9.90 \%)$ & $400-2300$ \\
\hline UBC840 & $(\mathrm{GA})_{8} \mathrm{YT}$ & 46.5 & 49 & 6 & 0 & $300-1300$ \\
\hline UBC841 & $(\mathrm{GA})_{8} \mathrm{YC}$ & 52.0 & 36 & 5 & $2(40.00 \%)$ & $400-2500$ \\
\hline UBC845 & $(\mathrm{CT})_{8} \mathrm{RG}$ & 47.5 & 71 & 13 & $1(7.69 \%)$ & $400-1800$ \\
\hline UBC854 & $(\mathrm{TC})_{8} \mathrm{RG}$ & 50.0 & 40 & 10 & 0 & $500-1800$ \\
\hline UBC855 & $(\mathrm{AC})_{8} \mathrm{YT}$ & 53.0 & 100 & 10 & 0 & $400-2000$ \\
\hline UBC856 & $(\mathrm{AC})_{8} \mathrm{YA}$ & 54.0 & 39 & 4 & 0 & $700-1500$ \\
\hline Total & & & 610 & 82 & $6(7.32 \%)$ & \\
\hline
\end{tabular}

Very low genetic distance values (about 0.1 ) were recorded between all samples (Table 5). This confirmed the clonal identity of the samples and that no somaclonal variation had resulted from the PGR treatments. Other than that, the morphology of the leaves of the in vitro grown plantlet and the mother plant was also compared. Figure 3 shows the morphology of a leaf from an in vitro grown Orthosiphon stamineus plantlet having a similar pattern with that of the mother plant. Both leaves showed serrated margin and visible pinnate veins. The uniform morphological characteristics between the mother plant and in vitro grown plantlet further strengthen the ISSR analysis results, thus confirming the clonal nature of the plantlets.

Table 5. Genetic distance based on Jaccard distance coefficient for of 10 random in vitro grown $O$. stamineus (OS) plantlets.

\begin{tabular}{ccccccccccc}
\hline & OS1 & OS2 & OS3 & OS4 & OS5 & OS6 & OS7 & OS8 & OS9 & OS10 \\
\hline OS2 & 0.110625 & & & & & & & & & \\
OS3 & 0.077377 & 0.110625 & & & & & & & & \\
OS4 & 0.021594 & 0.110625 & 0.077377 & & & & & & & \\
OS5 & 0.021594 & 0.110625 & 0.077377 & 0.021594 & & & & & & \\
OS6 & 0.077377 & 0.110625 & 0.077377 & 0.077377 & 0.077377 & & & & & \\
OS7 & 0.077377 & 0.110625 & 0.077377 & 0.077377 & 0.077377 & 0.077377 & & & & \\
OS8 & 0.077377 & 0.110625 & 0.077377 & 0.077377 & 0.077377 & 0.077377 & 0.000000 & & & \\
OS9 & 0.077377 & 0.110625 & 0.077377 & 0.077377 & 0.077377 & 0.077377 & 0.077377 & 0.077377 & & \\
OS10 & 0.077377 & 0.110625 & 0.077377 & 0.077377 & 0.077377 & 0.077377 & 0.000000 & 0.000000 & 0.077377 & \\
Mp & 0.124336 & 0.124336 & 0.124336 & 0.124336 & 0.124336 & 0.124336 & 0.124336 & 0.124336 & 0.124336 & 0.124336 \\
\hline
\end{tabular}

$\mathrm{Mp}$, mother plant; OS1 - OS10, in vitro-raised Ortosiphon stamineus plantlets.

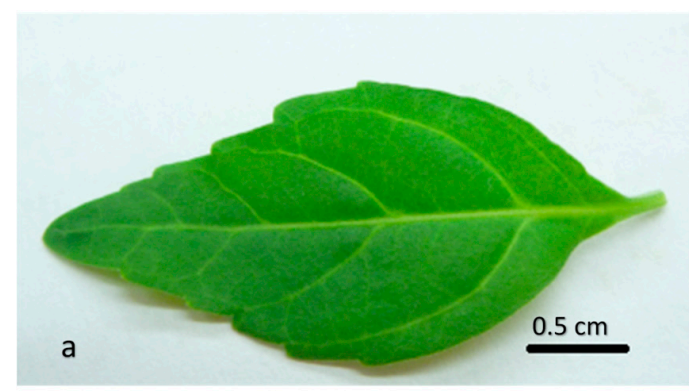

b

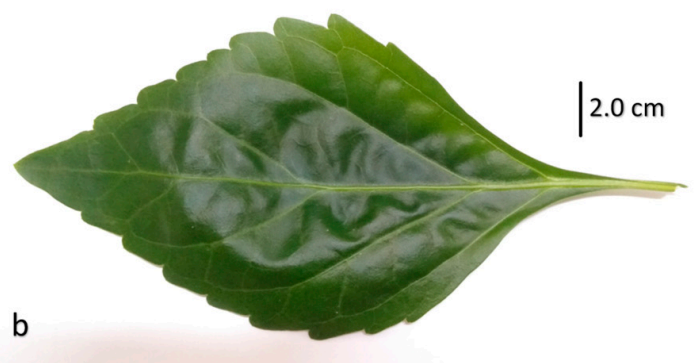

Figure 3. Morphology of leaves of Orthosiphon stamineus; (a) in vitro grown plantlet, and (b) mother plant. 


\section{Discussion}

Various PGRs have been used in tissue culture studies. Most tissue culture studies conducted on Orthosiphon employed the use of BAP (6-benzylaminopurinehormone) [18,33-35]. On the other hand, the current study evaluated the effectiveness of Kinetin as the exogenous cytokinin in improving shoot induction of this species. Both Kinetin and BAP were reported to generate high response (up to $90 \%$ ) in tissue culture of this species [36]. BAP was reported to be better for induction of multiple shoots, while Kinetin was found to induce longer shoot length compared to BAP $[20,35,37]$. In this study, $1.5-2.0 \mathrm{mg} \mathrm{L}^{-1}$ Kinetin supplemented singly was recorded to yield the highest number of shoots, similar to a previous report [20]. On the other hand, IAA was identified as the best auxin in adventitious root formation from leaf explants of O. stamineus, better than IBA and NAA [38]. Similar observation was recorded in this study, where media supplemented with $2.0 \mathrm{mg} \mathrm{L}^{-1}$ IAA was observed to produce the highest number of roots per explant $(4.60 \pm 0.65)$. Nevertheless, other studies have reported that IBA is a more effective rooting inducer than IAA [33,39-41]. However, it was observed that application of Kinetin together with IAA was not able to induce regeneration of roots.

Acclimatization of in vitro grown plantlets is a very crucial step, as it determines the success of any plant tissue culture experiment. During field transfer, in vitro grown plantlets are often unable to cope with the environmental conditions, such as exposure to high light intensity [42] and to compete with soil microbes [43]. One of the major limiting factors affecting the survival of acclimatized plantlets is humidity $[42,43]$. Gradually reducing humidity during hardening of the plantlets is key in ensuring survival of in vitro grown plantlets when taken ex vitro. In this study, the in vitro O. stamineus regenerants were gradually exposed to reduced levels of humidity, thus generating high survival percentages in all potting mixtures tested. A 100\% survival rate was maintained, even after 90 days of acclimatization, when the regenerants were grown on potting mixture PF, suggesting that 1:1:1 ratio of black soil/red soil/compost is the most suitable acclimatization medium for this species. The composition of potting mixture PF ensures good aeration with excellent water holding capacity, thus supporting the growth and survival of the plantlets after acclimatization.

Other than that, one of the main aims of mass propagation of plants through tissue culture is to generate clonal plantlets with superior quality. Thus, ensuring the genetic uniformity of tissue culture-raised plants is important for mass production of elite crops or cultivars such as rice [44], cotton [45], and sugarcane [46], as well as for conservation of endangered plant species [47-49]. Furthermore, plant tissue culture also allows for uniform production of clonal plants to be used as plant factories for production of novel and important bioactive compounds with medicinal properties [50,51]. Many marker systems have been used in assessments of genetic variation among clonal plants, such as random amplified polymorphic DNA (RAPD), inter-simple sequence repeat (ISSR), simple sequence repeat (SSR), and amplified fragment length polymorphism (AFLP). ISSR has been reported as a more effective molecular marker than RAPD and SSR [52-55]. Various reports have indicated that ISSR can reveal higher polymorphism than RAPD, such as in studies on Tilletia indica [56]. Usage of ISSR markers reveals a larger number of polymorphic fragments per primer than RAPD because of the occurrence of abundant SSR regions [57]. Due to this, ISSR has been suggested as an alternative to replace RAPD in genetic diversity assessment of coconut germplasm [52]. Moreover, ISSR is also able to detect higher similarity index than RAPD [55,58], possibly due to the abundant and highly polymorphic nature of the ISSR microsatellites caused by slippage in DNA replication [58]. ISSR has been widely used to help ascertain the clonal fidelity and to reveal any occurrence of somaclonal variation among tissue culture plants, such as Magnolia sirindhorniae Noot. \& Chalermglin [48], Abutilon indicum [59], Fritillaria dagana [60], Eleusine coracana (L.) Gaertn. [61], Smallanthus sonchifolius (Poepp. and Endl.) H. Robinson [31], Morus sp. [62], and bamboos [31,63].

Considered as one of the most important medicinal plants in Malaysia, Ortosiphon stamineus is widely planted in the country to support the nation's growing herbal industry [64]. However, environmental factors such as availability of soil nutrients, as well as other biotic and abiotic stresses, have been reported to influence and in some cases, hamper the production of important secondary 
metabolites in field-grown plants [65-67]. In this study, usage of ISSR markers revealed 7.32\% polymorphism and low genetic variation among the randomly collected samples. The low genetic distance among the tested samples confirms the clonal nature of the in vitro O. stamineus regenerants produced in this study. Thus, the in vitro regeneration protocol reported in this study is beneficial for both researchers and industry players alike, and is suitable for commercial mass propagation of this species.

\section{Conclusions}

Optimum regeneration media for micropropagation of $O$. stamineus has been successfully identified (MS media supplemented with $2.0 \mathrm{mg} \mathrm{L}^{-1}$ Kin plus $0.5 \mathrm{mg} \mathrm{L}^{-1} \mathrm{IAA}$ ) and yielded the highest number of shoots $(5.57 \pm 0.42)$ and leaves $(20.53 \pm 1.91)$ per explant. A 1:1:1 ratio of black soil/red soil/compost (potting mixture PF) was found to be the best acclimatization medium for this species, resulting in $100 \%$ survival percentage after 90 days of ex vitro transfer. Inter-simple sequence repeat (ISSR) was found to be a very useful tool to determine genetic differences among 10 randomly collected in vitro samples of $O$. stamineus. Very low polymorphism $(7.32 \%)$ was detected between all samples, thus ascertaining the clonal nature of the plantlets produced in this study.

Supplementary Materials: The following are available online at http://www.mdpi.com/2073-4395/9/12/778/s1, Table S1: List of primers used in the analysis [31].

Author Contributions: J.S.Y. and S.A.K. conceived and designed the experiments; H.A., I.F.M. and N.A.A.B. performed the experiments; H.A. and J.S.Y. analyzed the data; J.S.Y. and S.A.K. contributed reagents/materials/analysis tools; H.A. and J.S.Y. wrote the paper.

Funding: This research was funded by the University of Malaya, Malaysia; grant numbers CEBAR RU006-2018, RG297-14AFR, and PG156-2014B.

Acknowledgments: The authors thank the University of Malaya, Malaysia for experimental facilities and financial support (Grant Nos. CEBAR RU006-2018, RG297-14AFR, and PG156-2014B) provided.

Conflicts of Interest: The authors declare no conflicts of interest. The funders had no role in the design of the study; in the collection, analyses, or interpretation of data; in the writing of the manuscript; or in the decision to publish the results.

\section{References}

1. Almatar, M.; Rahmat, Z.; Salleh, F.M. Preliminary morphological and anatomical study of Orthosiphon stamineus. Asian J. Pharm. Biol. Res. 2013, 1,1-6. [CrossRef]

2. Akowuah, G.; Ismail, Z.; Norhayati, I.; Sadikun, A. The effects of different extraction solvents of varying polarities on polyphenols of Orthosiphon stamineus and evaluation of the free radical-scavenging activity. Food Chem. 2005, 93, 311-317. [CrossRef]

3. Bever, B.O.; Zahnd, G.R. Plants with Oral Hypoglycaemic Action. Q. J. Crude Drug Res. 1979, 17, 139-196. [CrossRef]

4. Olennikov, D.N.; Tankhaeva, L.M. Physicochemical characteristics and antioxidant activity of melanoidin pigment from the fermented leaves of Orthosiphon stamineus. Rev. Bras. Farmacogn. 2012, 22, 284-290. [CrossRef]

5. Awale, S.; Tezuka, Y.; Banskota, A.H.; Kadota, S. Siphonols A-E: Novel nitric oxide inhibitors from Orthosiphon stamineus of Indonesia. Bioorg. Med. Chem. Lett. 2003, 13, 31-35. [CrossRef]

6. Adam, Y.; Somchit, M.N.; Sulaiman, M.R.; Nasaruddin, A.A.; Zuraini, A.; Bustamam, A.A.; Zakaria, Z.A. Diuretic properties of Orthosiphon stamineus Benth. J. Ethnopharmacol. 2009, 124, 154-158. [CrossRef]

7. Olah, N.-K.; Radu, L.; Mogoşan, C.; Hanganu, D.; Gocan, S. Phytochemical and pharmacological studies on Orthosiphon stamineus Benth.(Lamiaceae) hydroalcoholic extracts. J. Pharm. Biomed. Anal. 2003, 33, 117-123. [CrossRef]

8. Matsubara, T.; Bohgaki, T.; Watarai, M.; Suzuki, H.; Ohashi, K.; Shibuya, H. Antihypertensive actions of methylripariochromene A from Orthosiphon aristatus, an Indonesian traditional medicinal plant. Biol. Pharm. Bull. 1999, 22, 1083-1088. [CrossRef] 
9. Yehya, A.H.S.; Asif, M.; Kaur, G.; Hassan, L.E.A.; Al-Suede, F.S.R.; Abdul Majid, A.M.S.; Oon, C.E. Toxicological studies of Orthosiphon stamineus (Misai Kucing) standardized ethanol extract in combination with gemcitabine in athymic nude mice model. J. Adv. Res. 2019, 15, 59-68. [CrossRef]

10. Robards, K.; Prernzler, P.D.; Tucker, G.; Swatsitang, P.; Glover, W. Phenolic compounds and their role in oxidative processes in fruits. Food Chem. 1999, 66, 401-436. [CrossRef]

11. Maheswari, C.; Maryammal, R.; Venkatanarayanan, R. Hepatoprotective activity of Orthosiphon stamineus on liver damage caused by paracetamol in rats. Jordan J. Biol. Sci. 2008, 1, 105-108.

12. Cai, X.; Xiao, C.; Xue, H.; Xiong, H.; Hang, Y.; Xu, J.; Lu, Y. A comparative study of the antioxidant and intestinal protective effects of extracts from different parts of Java tea (Orthosiphon stamineus). Food Sci. Nutr. 2018, 6, 579-584. [CrossRef] [PubMed]

13. Choo, B.K.M.; Kundap, U.P.; Kumari, Y.; Hue, S.M.; Othman, I.; Shaikh, M.F. Orthosiphon stamineus Leaf Extract Affects TNF-alpha and Seizures in a Zebrafish Model. Front. Pharmacol. 2018, 9, 139. [CrossRef]

14. Seyedan, A.; Alshawsh, M.A.; Alshagga, M.A.; Mohamed, Z. Antiobesity and Lipid Lowering Effects of Orthosiphon stamineus in High-Fat Diet-Induced Obese Mice. Planta Med. 2017, 83, 684-692. [CrossRef] [PubMed]

15. Nawi, I.M.; Samad, A.A. Successful plant regeneration of Orthosiphon stamineus from petiole. J. Med. Plants Res. 2012, 6, 4276-4280.

16. Affendy, H.; Aminuddin, M.; Azmy, M.; Amizi, M.; Assis, K.; Tamer, A. Effect of organic fertilizers application to the growth of Orthosiphon stamineus Benth. intercropped with Hevea brasiliensis Willd. and Durio zibethinus Murr. Int. J. Agric. Res. 2011, 6, 180-187.

17. Dhoran, V.; Gudadhe, S. Effect of plant growth regulators on seed germination and seedling vigour in Asparagus sprengeri Regelin. Int. Res. J. Biol. Sci. 2012, 1, 6-10.

18. Leng, L.W.; Lai-Keng, C. Plant regeneration from stem nodal segments of Orthosiphon stamineus Benth., a medicinal plant with diuretic activity. In Vitro Cell. Dev. Biol. Plant 2004, 40, 115-118. [CrossRef]

19. Zainuddin, Z. In-Vitro Regeneration Of Orthosiphon stamineus (Misai Kucing) Using Axillary Bud. Sci. Herit. J. 2019, 3, 8-10. [CrossRef]

20. Sheena, E.; Jeya Jothi, G. In vitro propagation of Orthosiphon stamineus Benth (Lamiaceae) an important medicinal plant using nodal and leaf explants. Pharma Innov. J. 2015, 4, 6-10.

21. Zarnadze, N.; Diasamidze, I.; Varshanidze, N.; Dolidze, K.; Bolkvadze, T. In vitro reproduction of Kidney Tea (Orthosiphon stamineus Bents). J. Pharm. Pharmacol. 2018, 6, 695-699. [CrossRef]

22. Wai-Leng, L.; Lai-Keng, C. Establishment of Orthosiphon stamineus cell suspension culture for cell growth. Plant Cell Tissue Organ Cult. 2004, 78, 101-106. [CrossRef]

23. Lim, F.L.; Yam, M.F.; Asmawi, M.Z.; Chan, L.-K. Elicitation of Orthosiphon stamineus cell suspension culture for enhancement of phenolic compounds biosynthesis and antioxidant activity. Ind. Crops Prod. 2013, 50, 436-442. [CrossRef]

24. Larkin, P.J.; Scowcroft, W.R. Somaclonal variation-A novel source of variability from cell cultures for plant improvement. Theor. Appl. Genet. 1981, 60, 197-214. [CrossRef]

25. Yaacob, J.S.; Loh, H.-S.; Mat Taha, R. Protein Profiling and Histone Deacetylation Activities in Somaclonal Variants of Oil Palm (Elaeis guineensis Jacq.). Sci. World J. 2013, 2013, 613635. [CrossRef]

26. Rani, V.; Raina, S. Genetic fidelity of organized meristem-derived micropropagated plants: A critical reappraisal. In Vitro Cell. Dev. Biol. Plant 2000, 36, 319-330. [CrossRef]

27. Leva, A.; Rinaldi, L.; Petruccelli, R. Somaclonal Variation in Tissue Culture: A Case Study with Olive; INTECH Open Access Publisher: London, UK, 2012.

28. Yaacob, J.S.; Mat Taha, R. Genetic stability of in vitro propagated African blue lily (Agapanthus praecox ssp. minimus). Caryologia 2014, 67, 227-233. [CrossRef]

29. Murashige, T.; Skoog, F. A revised medium for rapid growth and bio assays with tobacco tissue cultures. Physiol. Plant. 1962, 15, 473-497. [CrossRef]

30. Vujović, T.; Ružić, D.; Cerović, R. In vitro shoot multiplication as influenced by repeated subculturing of shoots of contemporary fruit rootstocks. Hortic. Sci. 2012, 39, 101-107. [CrossRef]

31. Viehmannova, I.; Bortlova, Z.; Vitamvas, J.; Cepkova, P.H.; Eliasova, K.; Svobodova, E.; Travnickova, M. Assessment of somaclonal variation in somatic embryo-derived plants of yacon [Smallanthus sonchifolius (Poepp. and Endl.) H. Robinson] using inter simple sequence repeat analysis and flow cytometry. Electron. J. Biotechnol. 2014, 17, 102-106. [CrossRef] 
32. Perrier, X.; Jacquemoud-Collet, J.P. DARwin Software. 2006. Available online: http://darwin.cirad.fr/ (accessed on 24 August 2019).

33. Reshi, N.A.; Sudarshana, M. In vitro micropropagation of Orthosiphon aristatus (Blume) Miq. J. Med. Plants Res. 2015, 9, 962-967.

34. Ignacimuthu, S.; Elangomathavan, R.; Prakash, S.; Kathiravan, K.; Seshadri, S. High frequency in vitro propagation of kidney tea plant. Plant Cell Tissue Organ Cult. 2003, 72, 83-86. [CrossRef]

35. Al Khateeb, W.; Bahar, E.; Lahham, J.; Schroeder, D.; Hussein, E. Regeneration and assessment of genetic fidelity of the endangered tree Moringa peregrina (Forsk.) Fiori using Inter Simple Sequence Repeat (ISSR). Physiol. Mol. Biol. Plants 2013, 19, 157-164. [CrossRef] [PubMed]

36. Veetil, S.E.; Gabriel, J.J. Comparative Phytochemical Screening and Antioxidant Properties of In Vitro and In Vivo Propagated Orthosiphon Stamineus Benth (Lamiaceae). Asian J. Pharm. Clin. Res. 2015, 8, 216-220.

37. Sridhar, T.M.; Aswath, C.R. Influence of Additives on Enhanced in Vitro Shoot Multiplication of Stevia rebaudiana (Bert.) - An Important Anti Diabetic Medicinal Plant. Am. J. Plant Sci. 2014, 5, 192-199. [CrossRef]

38. Ling, A.P.K.; Kok, K.M.; Hussein, S.; Ong, S.L. Effects of plant growth regulators on adventitious roots induction from different explants of Orthosiphon stamineus. Am.-Eurasian J. Sustain. Agric. 2009, 3, 493-501.

39. Hembrom, M.E.; Martin, K.; Patchathundikandi, S.K.; Madassery, J. Rapid in vitro production of true-to-type plants of Pogostemon heyneaus through dedieferentiated axillary buds. In Vitro Cell. Dev. Biol. Plant 2006, 42, 283-286. [CrossRef]

40. Nordine, A.; Bousta, D.; El Khanchoufi, A.; El Meskaoui, A. An efficient and rapid in vitro propagation system of Thymus hyemalis Lange, a wild medicinal and aromatic plant of Mediterranean region. Int. J. Pharma Biosci. Technol. 2013, 1, 118-129.

41. Saha, S.; Kader, A.; Sengupta, C.; Ghosh, P. In vitro propagation of Ocimum gratissimum L.(Lamiaceae) and its evaluation of genetic fidelity using RAPD marker. Am. J. Plant Sci. 2012, 3, 64. [CrossRef]

42. Marin, J. High survival rates during acclimatization of micropropagated fruit tree rootstocks by increasing exposures to low relative humidity. In Proceedings of the I International Symposium on Acclimatization and Establishment of Micropropagated Plants, Sani-Halkidiki, Macedonia, Greece, 19 September 2001; pp. 139-142.

43. Chandra, S.; Bandopadhyay, R.; Kumar, V.; Chandra, R. Acclimatization of tissue cultured plantlets: From laboratory to land. Biotechnol. Lett. 2010, 32, 1199-1205. [CrossRef]

44. Hoque, M.; Ali, M.; Karim, N. Embryogenic callus induction and regeneration of elite Bangladeshi Indica rice cultivars. Plant Tissue Cult. Biotechnol. 2007, 17, 65-70. [CrossRef]

45. Mishra, R.; Wang, H.-Y.; Yadav, N.R.; Wilkins, T.A. Development of a highly regenerable elite Acala cotton (Gossypium hirsutum cv. Maxxa)-A step towards genotype-independent regeneration. Plant Cell Tissue Organ Cult. 2003, 73, 21-35. [CrossRef]

46. Rashid, H.; Khan, S.A.; Zia, M.; Chaudhary, M.F.; Hanif, Z.; Chaudary, Z. Callus induction and regeneration in elite sugarcane cultivar HSF-240. Pak. J. Bot. 2009, 41, 1645-1649.

47. Dang, J.C.; Kumaria, S.; Kumar, S.; Tandon, P. Micropropagation of Ilex khasiana, a critically endangered and endemic holly of Northeast India. AoB Plants 2011, 2011. [CrossRef]

48. Cui, Y.; Deng, Y.; Zheng, K.; Hu, X.; Zhu, M.; Deng, X.; Xi, R. An efficient micropropagation protocol for an endangered ornamental tree species (Magnolia sirindhorniae Noot. \& Chalermglin) and assessment of genetic uniformity through DNA markers. Sci. Rep. 2019, 9, 9634.

49. Markovic, M.; Grbic, M.; Djukic, M. Micropropagation of Endangered and Decorative Species Dianthus pinifolius Sibth. et Sm. Braz. Arch. Biol. Technol. 2016, 59, e16150320. [CrossRef]

50. Ramirez-Estrada, K.; Vidal-Limon, H.; Hidalgo, D.; Moyano, E.; Golenioswki, M.; Cusidó, R.M.; Palazon, J. Elicitation, an effective strategy for the biotechnological production of bioactive high-added value compounds in plant cell factories. Molecules 2016, 21, 182. [CrossRef]

51. Dias, M.I.; Sousa, M.J.; Alves, R.C.; Ferreira, I.C. Exploring plant tissue culture to improve the production of phenolic compounds: A review. Ind. Crops Prod. 2016, 82, 9-22. [CrossRef]

52. Manimekalai, R.; Nagarajan, P.; Kumaran, P. Comparison of effectiveness of RAPD, ISSR and SSR markers for analysis of coconut (Cocos nucifera L.) germplasm accessions. Trop. Agric. Res. 2006, 18, 217.

53. Sornakili, A.; Rathinam, P.K.; Thiruvengadum, R.; Kuppusamy, P. Comparative assessment of RAPD and ISSR markers to study genetic polymorphism in Colletotrichum gloeosporioides isolates of mango. Asian J. Plant Pathol. 2017, 11, 130-138. [CrossRef] 
54. Rayar, J.K.; Arif, M.; Singh, U.S. Relative efficiency of RAPD and ISSR markers in assessment of DNA polymorphism and genetic diversity among Pseudomonas strains. Afr. J. Biotechnol. 2015, 14, 1097-1106.

55. Fernandez, M.; Figueiras, A.; Benito, C. The use of ISSR and RAPD markers for detecting DNA polymorphism, genotype identification and genetic diversity among barley cultivars with known origin. Theor. Appl. Genet. 2002, 104, 845-851. [CrossRef] [PubMed]

56. Parveen, S.; Saharan, M.; Verma, A.; Sharma, I. Comparative analysis of RAPD and ISSR marker assays for detecting genetic polymorphism in Tilletia indica. Eur. J. Exp. Biol. 2013, 3, 380-387.

57. Pathak, H.; Dhawan, V. ISSR assay for ascertaining genetic fidelity of micropropagated plants of apple rootstock Merton 793. In Vitro Cell. Dev. Biol. Plant 2012, 48, 137-143. [CrossRef]

58. Muthusamy, S.; Kanagarajan, S.; Ponnusamy, S. Efficiency of RAPD and ISSR markers system in accessing genetic variation of rice bean (Vigna umbellata) landraces. Electron. J. Biotechnol. 2008, 11, 32-41. [CrossRef]

59. Seth, S.; Panigrahi, J. In vitro organogenesis of Abutilon indicum (L.) Sweet from leaf derived callus and assessment of genetic fidelity using ISSR markers. J. Hortic. Sci. Biotechnol. 2019, 94, 70-79. [CrossRef]

60. Dinara, S.M.; Elena, V.K.; Tatyana, I.N. Assessment of Genetic Fidelity of Fritillaria dagana (Liliaceae) Regenerated Plants Using ISSR Markers. In Proceedings of the BIO Web of Conferences, Novosibirsk, Russia, 8-12 October 2018; p. 00029.

61. Babu, G.A.; Vinoth, A.; Ravindhran, R. Direct shoot regeneration and genetic fidelity analysis in finger millet using ISSR markers. Plant Cell Tissue Organ Cult. 2018, 132, 157-164. [CrossRef]

62. Rohela, G.K.; Jogam, P.; Shabnam, A.A.; Shukla, P.; Abbagani, S.; Ghosh, M.K. In vitro regeneration and assessment of genetic fidelity of acclimated plantlets by using ISSR markers in PPR-1 (Morus sp.): An economically important plant. Sci. Hortic. 2018, 241, 313-321. [CrossRef]

63. Mudoi, K.D.; Saikia, S.P.; Goswami, A.; Gogoi, A.; Bora, D.; Borthakur, M. Micropropagation of important bamboos: A review. Afr. J. Biotechnol. 2013, 12, 2770-2785.

64. Zakaria, M.H. Review of Policies and Issues in the Malaysian Herbal Industry; FFTC Agricultural Policy Articles; Food and Fertilizer Technology Centre (FTTC): Taiper, Taiwan, 2015.

65. Gonçalves, S.; Romano, A. Production of plant secondary metabolites by using biotechnological tools. In Secondary Metabolites: Sources and Applications; INTECH Open Access Publisher: London, UK, 2018; pp. 81-99.

66. Sampaio, B.L.; Edrada-Ebel, R.; Da Costa, F.B. Effect of the environment on the secondary metabolic profile of Tithonia diversifolia: A model for environmental metabolomics of plants. Sci. Rep. 2016, 6, 29265. [CrossRef]

67. Ncube, B.; Finnie, J.; Van Staden, J. Quality from the field: The impact of environmental factors as quality determinants in medicinal plants. S. Afr. J. Bot. 2012, 82, 11-20. [CrossRef] 